\title{
WIELKIE MOCARSTWA EUROPEJSKIE WOBEC WOJEN BAŁKAŃSKICH 1912-1913 ${ }^{1}$
}

\author{
JAROSŁAW RUBACHA
}

\begin{abstract}
Jarosław Rubacha, Wielkie mocarstwa europejskie wobec wojen bałkańskich 1912-1913 (The Great European Powers and Balkan Wars 1912-1913).
\end{abstract}

Balcanica Posnaniensia. Acta et studia, XIX, Poznań 2012, Wydawnictwo Instytutu Historii UAM, pp. 207-220, ISBN 978-83-63-047-17-7, ISSN 0239-4278. Polish text with a summary in English.

Jarosław Rubacha, Uniwersytet Warmińsko-Mazurski w Olsztynie, Instytut Dziennikarstwa i Komunikacji Społecznej, ul. Kurta Obitza 1, 10-725 Olsztyn, Polska - Poland.

W momencie wybuchu wojen bałkańskich zainteresowanie mocarstw europejskich Europą Południowo-Wschodnią miało już długą tradycję, a determinowane było ono dwoma ściśle ze sobą powiązanymi czynnikami. Pierwszy z nich określić można mianem ekonomicznego, a drugi politycznego.

Dynamicznie przebiegający proces industrializacji Europy już pod koniec pierwszej połowy XIX w. skłaniał rządy wiodących państw Starego Kontynentu do poszukiwania zarówno nowych baz surowcowych, jak i rynków zbytu dla swoich towarów. Tym samym wkraczanie mocarstw europejskich w tzw. erę imperialną wyrażało się $\mathrm{m}$. in. poprzez stałe poszerzenie zasięgu posiadłości kolonialnych oraz działaniami na rzecz poszerzenia stref wpływów w różnych częściach świata. $Z$ tego punktu widzenia Bałkany odgrywały bardzo istotną rolę. Stanowiły one, bowiem, swego rodzaju łącznik pomiędzy Europą a Azją i były ważnym elementem znanej już od czasów antycznych drogi handlowej wiodącej z Europy Północnej i Środkowej, a częściowo także Zachodniej, do Azji Mniejszej i dalej - w kierunku Azji Centralnej i na Daleki Wschód. Istotnym elementem był również fakt, że Turcja i jej bałkańskie posiadłości były cennym odbiorcą towarów wytwarzanych przez europejski przemysł,

${ }^{1}$ Działania dyplomatyczne podejmowane przez mocarstwa europejskie w czasie wojen bałkańskich 1912-1913 stanowią niezwykle obszerną i złożoną problematykę, która stanowić by mogła treść obszernej monografii. Stąd też, w związku z ograniczoną objętością niniejszego artykułu, autor dokonał selekcji jedynie najistotniejszych jego zdaniem wątków. 
co podyktowane było stosunkowo wysokim rozwojem cywilizacyjnym jej obywateli. Warto także podkreślić, że rola Turcji w strukturze europejskiego eksportu stale rosła od lat 30. XIX w. Wynikało to stąd, że państwo to rozpoczęło w tym czasie realizację szerokiego programu reform wewnętrznych, nazywanego erą tanzymatu ${ }^{2}$ obejmującego niemal wszystkie dziedziny życia społecznego. Efektem zmian miało być stworzenie nowoczesnego państwa na wzór krajów zachodnioeuropejskich. Trudno zatem dziwić się, że Turcja potrzebowała nie tylko zagranicznych kapitałów, znacznej liczby doradców-specjalistów reprezentujących różne dziedziny wiedzy, ale także dużej ilości specjalistycznych towarów produkowanych w Europie. To z kolei czyniło z niej ważnego partnera ekonomicznego, tym bardziej, że rząd turecki, stale borykający się z poważnymi problemami finansowymi, w zamian za dostarczane produkty chętnie przyznawał liczne koncesje i zwolnienia celne. Sytuację tę starały się początkowo wykorzystać Wielka Brytania i Francja, które rywalizując ze sobą o wpływy w Turcji, inwestowały znaczne kapitały, zarówno państwowe, jak i prywatne, w rozwój państwa tureckiego, ale w miarę upływu czasu dołączały do nich także inne wiodące państwa europejskie.

Drugi czynnik warunkujący zainteresowanie mocarstw Europa PołudniowoWschodnią określić można mianem politycznego. W jego ramach wyodrębnić można dwa podstawowe aspekty. Pierwszy z nich dotyczył swego rodzaju rywalizacji o przodownictwo polityczne i ekonomiczne na Starym Kontynencie, którą wiodące państwa europejskie rozpoczęły już w pierwszej połowie XIX w. Cechą charakterystyczną podejmowanych $\mathrm{w}$ jego ramach działań, była chęć zablokowania wysiłków przedsiębranych przez konkurentów, co wielokrotnie prowadziło do tworzenia się szerszych i węższych koalicji, czasami wręcz egzotycznych. Drugi aspekt ściśle wiązał się z czynnikiem ekonomicznym, a podejmowane działania natury politycznej, miały na celu zagwarantowanie swobody wymiany towarowej i możliwie najwyższych zysków z handlu. W kontekście bałkańskim przekładało się to przede wszystkim na zaostrzenie się walki o strefy wpływów, w trakcie której starano się wspierać i wykorzystywać lokalne ruchy narodowowyzwoleńcze, coraz silniejsze i aktywniejsze w tej części Europy.

W połowie XIX w. można wyodrębnić dwa regiony na Półwyspie Bałkańskim, które stały się obiektem szczególnego zainteresowania mocarstw. Pierwszym z nich były Bałkany Zachodnie, a w szczególności Bośnia i Hercegowina oraz ziemie albańskie, na których swoje wpływy starała się utrwalić Austria, a następnie Austro-Węgry. Podejmowane przez to mocarstwo działania polityczne miały na celu opanowanie wygodnej drogi i zapewnienie swobodnego dostępu do portu w Salonikach, który w Wiedniu uznawano za naturalny port dla austriackiej wymiany handlowej ${ }^{3}$. Drugim

${ }^{2}$ Na ten temat szerzej: T. Wituch, Tureckie przemiany. Dzieje Turcji 1878-1923, Warszawa 1980, s. 11-19, E. F. Knight, Turkey. The Awakening of Turkey the Turkish Revolution of 1908, Boston/Tokyo 1910, s. 25-34.

${ }^{3}$ Zob. W. Miller, Travels and Politics in the Near East, London 1898, s. 388, M. I. Newbigin, Geographical Aspects of Balkan Problams in their Relation to Great European War, London 1915, s. 37, na ten temat także: K. Srokowski, Austrya na rozdrożu, „Tygodnik Ilustrowany“, 1913, nr 54, s. 102,. 
regionem były natomiast cieśniny czarnomorskie i leżące w ich okolicach ziemie bułgarskie, niezwykle istotne dla eksportu rosyjskiego zboża z terenów Ukrainy przez Morze Czarne i Śródziemne do Europy Zachodniej. Warto podkreślić, że podejmowane przez Petersburg zabiegi na rzecz zabezpieczenia swoich interesów w tej części kontynentu miały zarówno charakter działań dyplomatycznych, w trakcie których starano się zapewnić swobodny ruch floty handlowej przez Bosfor i Dardanele, jak i operacji wojennych, które zmusić miały Turcję do zagwarantowania otwarcia cieśnin dla rosyjskiego handlu. Pozostałe mocarstwa w tym okresie, w obawie o swoje własne interesy, albo podejmowały działania na rzecz zabezpieczenia integralności tureckiego terytorium na Bałkanach, albo nie angażowały się w spory w tej części Europy. Zasadnicze zmiany w politycznej działalności wielkich mocarstw na Bałkanach i w Turcji przyniosły jednak dopiero: wojna rosyjsko-turecka 1877-18785, a zwłaszcza kończące ją traktaty pokojowe z San Stefano i Berlina ${ }^{6}$.

Zwycięstwo Rosji w konfrontacji z Wysoką Portą i lansowana przez Petersburg w traktacie sanstefańskim koncepcja fundamentalnych zmian w Europie PołudniowoWschodniej mocno zaniepokoiły dyplomację austro-węgierską. W Wiedniu w działaniach rosyjskich dostrzegano, bowiem, zagrożenie dla własnych wpływów na Półwyspie Bałkańskim, a szczególnie obawiano się utworzenia Wielkiej Bułgarii, której granice niebezpiecznie zbliżyć się miały do Adriatyku. Słusznie podejrzewano, że Rosja tworząc niezależne księstwo bułgarskie, planuje utworzyć z niego państwo całkowicie od siebie zależne, co w efekcie doprowadziłoby do poważnego zachwiania układu sił politycznych na Bałkanach ${ }^{7}$. Obawiano się także, że w przyszłości, kierowana faktycznie przez Rosję Bułgaria, pokusi się o opanowanie albańskich wybrzeży Adriatyku, co z jednej strony na zawsze mogło zamknąć możliwość uzyskania przez Austro-Węgry nabytków terytorialnych na południu, a z drugiej strony stworzy możliwość powstania rosyjskiej bazy morskiej w zachodniej części Półwyspu

4 Zob. A. Krzyżanowski, Wojna batkańska w roku 1912/13. Odbitka z „Przegladu Powszechnego”, Kraków 1913, s. 74, M. Tanty, Rosja wobec wojen batkańskich 1912-13, Warszawa 1970, s. 38 i n., H. Batowski, Cieśniny tureckie 1911-1936, Warszawa 1936, M. Tanty, Bosfor i Dardanele w polityce mocarstw, Warszawa 1982, M. Tanty, Rosja wobec wojen batkańskich 1912-13, Warszawa 1970, s. 38-52, H. Batowski, Cieśniny Tureckie 1911-1936, Warszawa 1936, s. 5-6.

${ }^{5} \mathrm{Na}$ ten temat m. in.: Руско-турската война (1877-1878 г.). Дневници, спомени, записки, кореспондениия, София 1998; Руско-турската война 1877-1878. Хроника, София 1988; Россия и наиионально-освободительная борьба на Балканах 1875-1878, ред. А. С. Нароцницкий, Москва 1978, К. Косев, С. Дойнов, Освободительна война 1877-1878 и българската национальна революция, София 1988, М. Tanty, Mocarstwa europejskie wobec kryzysu batkańskiego w latach 1875-1978, „Pamiętnik Słowiański”, 1977, t. XXVII, s. 25-39, Z. Klejn, Polskie ślady w budownictwie nowożytnej Butgarii 1877-1914, Łowicz 1999, s. 55-75, A. Giza, Działania zbrojne wielkiego kryzysu bałkańskiego (1875-1878) i udział w nich Polaków, „Studia i materiały do historii wojskowości”, t. XXVII, 1984.

${ }^{6} \mathrm{Na}$ ten temat szerzej: J. Rubacha, Butgarski sen o Bizancjum. Polityka zagraniczna Butgarii w latach 1878-1913, Warszawa 2004, s. 13-16, 23-26; teksty obu dokumentów w: J. Rubacha, A. Malinowski, A. Giza, Historia Butgarii 1870-1915. Materiały źródłowe z komentarzami, t. 1, Warszawa 2006, s. 21$-32,36-55$.

7 Zob. T. von Sosnosky, Die Balkanpolitik Österreich-Ungarns seit 1866, Stuttgart / Berlin 1914, s. 74 . 
Bałkańskiego, w pobliżu głównego austriackiego portu wojennego w Trieście. Poza tym rząd wiedeński czuł się oszukany przez Rosję, ponieważ jeszcze w styczniu 1877 r. w Budapeszcie oba państwa podpisały tajny układ poprzedzony rozmowami w Reichstadt, który przewidywał, że w przypadku wojny rosyjsko-tureckiej monarchia habsburska zachowa neutralność w zamian za prawo do okupacji Bośni i Hercegowiny, a Rosja nie będzie prowadzić działań wojennych w zachodniej części Półwyspu i w przypadku pokonania Turcji, nie utworzy dużego państwa słowiańskiego na Bałkanach ${ }^{8}$. Zagrożenie dla swej sfery wpływów w działaniach rosyjskich widziała także Wielka Brytania. Jej uwaga skupiona była jednak na wschodniej części Półwyspu Bałkańskiego, a brytyjski premier B. Disraeli zwracał uwagę, że przesunięcie granic Bułgarii do wybrzeży Morza Egejskiego i oddanie jej portu Kavala stworzy szczególnie niebezpieczną sytuację w okolicach cieśnin czarnomorskich. Gwarantowałoby to, bowiem, pełną rosyjską kontrolę Bosforu i Dardaneli oraz stwarzałoby stałe zagrożenie dla Konstantynopola9. Pozostałe mocarstwa, pozornie mniej zainteresowane kwestią wschodnia, równo podzieliły swoje poparcie. Francja, mocno jeszcze osłabiona po wojnie z Prusami, nie zamierzała wywierać na Petersburg silnego nacisku. Niemniej jednak podejmowane od lat starania o uniemożliwienie Rosji kontroli nad Bosforem i Dardanelami, postawiły ją u boku Wielkiej Brytanii; Włochy, także jeszcze słabe, ale już żywotnie zainteresowane roztoczeniem swej kurateli nad Albanią, nie godziły się na oderwanie od niej najmniejszego choćby skrawka terytorium i popierały austro-węgierskie koncepcje odepchnięcia Rosjan od zachodnich Bałkanów. To zgodne stanowisko innych mocarstw skłoniło ostatecznie Rosję do wyrażenia zgody na weryfikację postanowień traktatu pokojowego z San Stefano w trakcie międzynarodowej konferencji odbywającej się latem $1878 \mathrm{r}$. w Belinie ${ }^{10}$.

Kongres berliński, poza udaremnieniem rosyjskich planów dotyczących zmian na Półwyspie Bałkańskim, posiadał doniosłe znaczenie w jeszcze dwóch obszarach. Po pierwsze jego efektem było aktywne włączenie się w rywalizację o wpływy na Bałkanach, a zwłaszcza w Turcji, nowego konkurenta - Niemiec. Sukces w wojnie z Francją oraz pomyślnie zakończony proces zjednoczenia ziem niemieckich wykształcił w Berlinie przekonanie, że nadszedł odpowiedni moment na rozpoczęcie działań na rzecz wykreowania państwa na lidera politycznego i ekonomicznego w Europie ${ }^{11}$. Tym samym walka o „palmę pierwszeństwa” zmuszała rząd niemiecki do podjęcia aktywnej polityki bałkańskiej ${ }^{12}$. Po drugie kongres berliński usankcjonował utworzenie w Europie Południowo-Wschodniej niezależnych państw na-

${ }^{8} \mathrm{Na}$ ten temat szerzej: ibidem, s. 151-160.

${ }^{9}$ Zob. L. S. Stavrianos, The Balkans since 1453, New York 1963, s. 405-406.

${ }^{10} \mathrm{Na}$ ten temat szerzej m. in: С. Пенков, Берлинският договор и балканите, София 1985, s. 9-25, L. S. Stavrianos, op. cit, s. 407.

11 Zob. R. Poincaré, Geneza wojny światowej. Sześć odczytów w Paryżu w 1921 r., Kraków 1921, s. 26.

12 Na ten temat szerzej: H. Bechtel, Wirtschaftsgeschichte Deutschlands in 19. und 20 Jahrhundert, München 1956, s. 175-180, H. Mottek, W. Becker, A. Schröter, Wirtschaftsgeschichte Deutschlands. Ein Grundriß, t. 3, Berlin 1975, 224-251. 
rodowych. Tym samym na politycznej mapie kontynentu pojawiła się grupa nowych partnerów politycznych, którzy bardzo szybko stali się istotnym elementem dyplomatycznej gry wielkich mocarstw. Warto podkreślić, że ich rola stale rosła, a zainteresowanie pozyskaniem ich do ewentualnej współpracy przeciw konkurentom osiągnęło swoje apogeum w finalnej fazie krystalizowania się przeciwstawnych bloków militarno-politycznych w Europie - Trójprzymierza i Ententy - na początku XX w. Istotnym wydaje się jednak zwrócenie uwagi także na fakt, że arbitralne rozstrzygnięcia traktatu berlińskiego, mające w pierwszym rzędzie zabezpieczać interesy mocarstw w regionie, stanowiły zawód dla państw bałkańskich i skłaniały je do podejmowania wysiłków na rzecz realizacji własnych celów politycznych na własną rękę. Konsekwencją nałożenia się tych dwóch czynników - rywalizacji mocarstw o strefy wpływów z jednej oraz dążeń państw i narodów bałkańskich z drugiej strony - przekładało się natomiast na wzrost napięcia Półwyspie Bałkańskim i całej Europie.

Podejmując próbę charakterystyki działań wielkich mocarstw w okresie wojen bałkańskich zasadnym wydaje się rozpoczęcie analizy od roku 1908. W tym bowiem czasie miały miejsce dwa niezwykle istotne wydarzenia. Pierwszym z nich była aneksja Bośni i Hercegowiny przez Austro-Węgry ${ }^{13}$, która stanowiła przełomowy moment w dziejach Bałkanów i bardzo istotny punkt w historii Europy. W tym pierwszym kontekście podjęte przez monarchię habsburską kroki dały państwom bałkańskim wyraźny sygnał do rozpoczęcia działań na rzecz realizacji swych własnych planów narodowych. Naruszenie ducha traktatu berlińskiego przez jednego z sygnatariuszy dokumentu świadczyło, bowiem, że postanowienia mocarstw nie mają charakteru ostatecznego i mogą zostać w przyszłości zmienione. W drugim kontekście aneksja Bośni i Hercegowiny, której efektem był tzw. kryzys bośniacki w latach 1908-1909, jeszcze bardziej zaogniła stosunki między Trójprzymierzem i Ententą, co niemal nie doprowadziło do wybuchu konfliktu między tymi blokami. Jednocześnie wpłynęło to na intensyfikację działań w zakresie poszukiwania potencjalnych sojuszników, co pośrednio przyczyniło się do stworzenia na początku 1912 r. bloku państw bałkańskich. Drugim istotnym wydarzeniem w $1908 \mathrm{r}$. była rewolucja młodoturecka ${ }^{14}$, której efektem było przekształcenie Turcji w monarchię konstytucyjną. Szczytne hasła równości i wolności, głoszone przez komitet „Jedność i Postęp” w trakcie walki o władzę, skłoniły mocarstwa europejskie do przerwania akcji reformatorskiej, prowadzonej od 1903 r. w Macedonii ${ }^{15}$. Bardzo szybko okazało się jednak, że za parawanem oficjalnej propagandy młodoturcy zamierzają zrealizować własne cele polityczne, które przewidywały przede wszystkim wskrzeszenie świetności państwa tureckiego ${ }^{16}$. Stąd też, wkrótce po przejęciu rządów, rozpoczęli oni m.in. działania na rzecz konsolidacji wewnętrznej kraju, co przyniosło zwiększenie ucisku narodowego nietureckiej ludno-

${ }^{13} \mathrm{Na}$ ten temat szerzej: J. Rubacha, op. cit., s. 122-134.

14 Zob. T. Wituch, op. cit., s. 80 -88 i n, H. Batowski, Zagadnienia bałkańskie, Kraków 1939, s. 77.

${ }^{15} \mathrm{Na}$ ten temat szerzej: H. Batowski, Państwa..., s. 147, A. Giza, Państwa bałkańskie..., s. 81-85, H. W. Steed, The Hapsburg Monarchy, London 1919, s. 228

${ }^{16}$ Zob. L. Trotsky, The Balkan wars, 1912-13, New York 1980, s. 30-31. 
ści na Bałkanach, a w konsekwencji motywowało państwa regionu do zacieśnienia współpracy na rzecz poprawy położenia ludności chrześcijańskiej w europejskich posiadłościach Turcji.

Aneksja Bośni i Hercegowiny rozpoczęła także nowy etap w rywalizacji mocarstw o poszerzenie stref wpływów, względnie umocnienie swych pozycji na Bałkanach, które nieprzerwanie prowadzone były aż do zakończenia wojen bałkańskich w $1913 \mathrm{r}$. Działania w tym obszarze podzielić można ogólnie na trzy zasadnicze okresy.

Pierwszy z nich, trwający od lata 1909 do jesieni 1912 r., zawiera w sobie dwie fazy.

W trakcie pierwszej (czerwiec 1909 - lipiec 1912) wielkie mocarstw podjęły próby stworzenia na Bałkanach bloku państw tego regionu i wykorzystania go dla własnych celów politycznych. Działania w tym zakresie, już na przełomie 1908 i 1909 r., rozpoczęła Rosja, poważnie zaniepokojona potencjalnymi konsekwencjami aneksji Bośni i Hercegowiny oraz wzrostem wpływów mocarstw centralnych na Półwyspie Bałkańskim. Początkowo jednak akcja ta nie przynosiła sukcesu. Jakkolwiek dyplomacji rosyjskiej udało się odbudować swe wpływy w Bułgarii i doprowadzić do wyciszenia antagonizmów bułgarsko-serbskich, zaproponowany przez posła rosyjskiego w Konstantynopolu M. Czarykowa plan utworzenia sojuszu pod egidą Turcji1" nie został przychylnie przyjęty w stolicach państw bałkańskich. Te bowiem widziały głównego przeciwnika w Wysokiej Porcie i w konfrontacji z nią zamierzały realizować swoje cele. Warto jednak podkreślić, że zapoczątkowane w tym okresie próby zbliżenia dwóch najsilniejszych państw na Bałkanach - Bułgarii i Serbii - przyniosły ostatecznie pozytywne skutki, a dzięki wysiłkom dyplomatów rosyjskich w Sofii i Belgradzie, wiosną 1912 r., stworzony został trzon późniejszego bloku bałkańskiego, którego podstawę stanowił bułgarsko-serbski układ sojuszniczy ${ }^{18}$. Pozostali członkowie Ententy nie podejmowali w tym czasie szerzej zakrojonych działań. Zarówno Francja, jak i Wielka Brytania, ogólnie informowane o przebiegu toczących się pod egidą Petersburga rozmów, generalnie z zadowoleniem przyjęły ideę stworzenia sojuszu, który w ich mniemaniu nie tylko miał stabilizować sytuację na Bałkanach, ale także stanowić ważny element sfery wpływów Trójporozumienia w Europie Południowo-Wschodniej i tamę dla wpływów mocarstw centralnych w tym regionie. Stąd też partnerzy Rosji tylko okazjonalnie starali się pozyskiwać informacje na temat zakresu prowadzonych dyskusji i bezpośrednio nie angażowali się w negocja$\mathrm{cje}^{19}$. Zupełną ignorancją polityczną wykazywały się natomiast w tym czasie mocarstwa centralne, które mimo obiegających Europę plotek na temat tworzącego się pod patronatem Rosji sojuszu nie podejmowały niemal żadnych działań dyplomatycznych

${ }^{17} \mathrm{Na}$ ten temat szerzej: J. Rubacha, op. cit., s. 155-158 i n.

18 Zob. ibidem, s. 169-178 i n.

${ }^{19}$ Swego rodzaju wyjątkiem była inicjatywa rządu brytyjskiego, który wiosną $1911 \mathrm{r}$. zapośredniczył rozmowy bułgarsko-greckie; zob. J. Wiśniewski, Rywalizacja ekonomiczna Francji i Niemiec na Batkanach w okresie poprzedzajacym wybuch I wojny światowej w: Polityka batkańska polityce imperializmu niemieckiego w latach 1871-1945 - referaty z sympozjum Zakładu Historii Powszechnej i Najnowszej Instytutu Historii UAM w Poznaniu w 1980 r., red. A. Czubiński, Poznań 1982, s. 63-64. 
w celu ich weryfikacji tych informacji. Taka postawa Niemiec i Austro-Węgier podyktowana była przeświadczeniem, że jakiekolwiek próby związania porozumieniem państw bałkańskich, wrogo do siebie nastawionych w związku z rywalizacją na terenie Macedonii, nie jest możliwe, co potwierdzać miało fiasko działań podjętych przez Czarykowa. Dzięki temu wiosną i latem 1912 r. możliwe stało się utworzenie sojuszu bałkańskiego obejmującego Bułgarię, Serbię, Grecję i Czarnogórę.

Druga faza $w$ ramach tego okresu obejmowała czasokres pomiędzy sierpniem a październikiem $1912 \mathrm{r}$. i wiązała się z bezpośrednimi działaniami mocarstw na rzecz zachowania pokoju na Bałkanach.

Ujawnienie informacji na temat rzeczywistych celów sojuszników bałkańskich w czerwcu 1912 r., wywołało znaczne poruszenie w stolicach europejskich. Bardzo szybko uświadomiono sobie, bowiem, że wybuch wojny na Półwyspie Bałkańskim może stanowić poważne zagrożenie dla ogólnoeuropejskiego pokoju. Tym samym wielkie mocarstwa podjęły zgodne działania na rzecz rozładowania niebezpiecznej sytuacji, a w prace włączyła się aktywnie także dyplomacja rosyjska ${ }^{20}$. Pogarszająca się sytuacja na Bałkanach już w połowie sierpnia 1912 r. skłoniła austro-węgierskiego ministra spraw zagranicznych L. Berchtolda do wysłania do innych mocarstw memorandum w sprawie wspólnej akcji dyplomatycznej w Turcji i w państwach bałkańskich. Propozycja ta spotkała się z poparciem Wielkiej Brytanii i Francji oraz zainteresowaniem innych mocarstw, ale jednocześnie powszechne było przekonanie, że tego typu akcja nie zakończy się sukcesem. W związku z tym propozycja Berchtolda została odrzucona. Nie oznaczało to jednak zaprzestania prób zażegnania kryzysu na Bałkanach. Na początku września 1912 r. z inicjatywy Rosji stworzony został rosyjsko-francuski plan nacisku na Turcję w kwestii ostatecznego wprowadzenia reform w Macedonii, co odebrałoby sojusznikom bałkańskim główny argument do wypowiedzenia wojny Wysokiej Porcie. Jakkolwiek propozycja ta zyskała poparcie innych mocarstw, dyskusje nad szczegółami planu przeciagały się i ostatecznie nie został on zrealizowany. Równocześnie jednak Francja rozpoczęła bezpośrednie rozmowy z Niemcami, a efektem przeprowadzonych konsultacji był ogłoszony 3.10.1912 r. plan akcji mediacyjnej, którą prowadzić miały wspólnie Rosja i AustroWęgry. Mimo że także ten plan został przyjęty z zadowoleniem przez inne mocarstwa, narady nad detalami znowu się przeciagały, a wspólna nota „koncertu europejskiego" została przekazana do stolic państw bałkańskich dopiero 8.10.1912 $\mathrm{r}^{21} \mathrm{~W}$

${ }^{20}$ Wynikało to z faktu, ze rząd rosyjski nie do końca orientował się w poszczególnych klauzulach zawieranych sojuszy. Pełną treść układu serbsko-bułgarskiego poznano dopiero w maju 1912 r., po przedstawieniu jej przez Serbów i Bułgarów carowi Mikołajowi II w Liwadii; zob. И. Е. Гешов, Балканский Союз. Воспоминания и документы, Петроград 1915, s. 35 Ofensywne zapisy traktatu stanowity dla gabinetu rosyjskiego duże zaskoczenie. Stąd Rosja postanowiła solidarnie z innymi mocarstwami przedsiębrać działania na rzecz zabezpieczenia pokoju na Półwyspie Bałkańskim; zob. G. Rollof, Die Entstehung des Balkanbundes von 1912. Akademische Rede zur Jahresfeier der Hess. Ludvigs-Universität am 1. Juli 1922, Geissen 1922, s. 19, M. Tanty, Rosja ..., s. 61, J. Rubacha, op. cit., s. 180-181.

${ }^{21}$ Zob. Österreich-Ungarns Aussenpolitik von bosnischen Krise 1908 bis zum Kriegsausbruch 1914. Diplomatische Aktenstücke des Österreich-Ungarischen Aussenministeriums, ausgewählt von L. Bittner, 
tym czasie nikt na Bałkanach nie myślał już o stosowaniu się do zaleceń mocarstw. Przygotowania wojenne zostały ukończone i dziesięć dni późniejeje sojusznicy bałkańscy wypowiedzieli wojnę Turcji Osmańskiej.

Tym samym działania wielkich mocarstw w pierwszym okresie ich wzmożonej aktywności ocenić należy krytycznie. Nie tylko nie panowały one nad przebiegiem prowadzonych na Bałkanach rozmów, bagatelizując drążenia państw bałkańskich, ale ostateczny kształt zawartych wiosną i latem 1912 r. porozumień daleko odbiegał od planów „koncertu europejskiego”. Niepowodzeniem zakończyły się także próby nacisku na sojuszników bałkańskich i Turcję oraz zabiegi na rzecz ratowania pokoju. Państwa bałkańskie, starając się wykorzystać sprzyjający im zbieg okoliczności, nie zamierzały rezygnować z założonych planów i po raz pierwszy wspólnie przystąpiły do realizacji hasła „Bałkany dla narodów bałkańskich”.

Drugi okres aktywnej działalności wielkich mocarstw w okresie wojen bałkańskich przypada na czas trwania konfliktu ${ }^{23}$ i zawiera się pomiędzy połową października 1912 a końcem maja 1913 r. Także w tym przypadku można wyodrębnić dwie wyraźne fazy. Pierwsza z nich przypada na okres działań wojennych w toku I wojny bałkańskiej (październik - grudzień 1912). W tym czasie mocarstwa europejskie, nadal zgodnie współpracując, skupiły swoją uwagę na działaniach mających na celu możliwie szybkie zminimalizowanie zasięgu działań wojennych. W tym kontekście pierwszoplanową kwestią stało się niedopuszczenie do zajęcia Konstantynopola przez którąś z armii sojuszników bałkańskich. Starając się przeciwdziałać takiemu zagrożeniu, „koncert europejski” przedsięwziął odpowiednie kroki. Już na początku listopada 1912 r. na Morze Śródziemne zostały skierowane eskadry okrętów wojennych ${ }^{24}$, z których część odesłano następnie do Konstantynopola ${ }^{25}$, gdzie z ich załóg sformowany został międzynarodowy korpus pod dowództwem francuskiego wiceadmirała L. du Fournet'a. Jakkolwiek liczący około 2.500 ludzi oddział nie mógł obronić tureckiej stolicy przez ewentualnym zajęciem jej przez wojska bułgarskie, miał on manifestować negatywny stosunek mocarstw do ewentualnych prób opanowania mia$\mathrm{sta}^{26}$. Akcja militarna okazała się jednak zbędna. Armia bułgarska została zatrzymana

A. F. Pribram, H. Srbik und H. Übersberger, t. 4, Wien / Leipzig 1930, (cyt. dalej ÖUA), nr 4009, 4010, 4018, 4019, 4020, A. Krzyżanowski, op. cit., s. 82, H. Batowski, Państwa..., op. cit., s. 188, T. von Sosnosky, op. cit., s. 279 i W. Schröder, England, Europa und der Orient, Stuttgart 1938, s. 144-145.

22 Poza Czarnogórą, która działania wojenne rozpoczęła już 7.10.1912 r.

${ }^{23} \mathrm{Na}$ ten temat szerzej: J. Rubacha, op. cit., s. 243-266.

24 Zob. ÖUA, t. 4, nr 4252, Международные отношения в епоху империялизма. Документи ин архивов царского и временного правительств 1878-1917, s. II, 1900-1913, t. 21, Москва-Ленинград 1939-1940, t. 21, cz. 1, nr 147, 179, 180.

${ }^{25}$ Zob. J. Gozdawa-Gołębiewski, Od wojny krymskiej do bałkańskiej. Działania flot wojennych na morzach i oceanach w latach 1853-1914, Gdańsk 1985, s. 118, Международные отночения, t. 21, cz. 1, nr 181, 227

${ }^{26}$ Warto także zaznaczyć, że w tym czasie mocarstwa negatywnie odnosiły się także do planów zajęcia przez Bułgarów twierdzy w Adrianopolu. Jeszcze w listopadzie 1912 Rosja nie przewidywała możliwości przyłączenia do Bułgarii ani wilajetu adrianopolskiego, ani samego miasta i propagowała tezę, że nawet w przypadku zdobycia twierdzy przez armię bułgarską, powinno ono bezzwłocznie zostać przeka- 
na linii Czataldży, a 3.12.1912 r. sojusznicy bałkańscy podpisali z Turcją zawieszenie broni $^{27} \mathrm{i}$ zdecydowali o rozpoczęciu rozmów pokojowych w Londynie. Decyzja ta została przyjęta z zadowoleniem przez wielkie mocarstwa. Jednocześnie „koncert europejski" postanowił, że w Londynie rozpocznie obrady konferencja ambasadorów, której zadaniem będzie wspieranie negocjacji pokojowych oraz czuwanie nad kwestiami, które z punktu widzenia jego członków posiadały szczególne znaczenie.

Tym samym druga faza (grudzień 1912 - maj 1913) aktywnych działań przypadła na czas trwania konferencji pokojowej w Londynie, a jej najistotniejszym elementem była tzw. kwestia albańska. W toku działań wojennych przeciw Turcji, Serbowie mieli do wykonania relatywnie łatwe zadanie - rozbicie sił tureckich w Macedonii. Dokonali tego w bitwach pod Kumanovem i Monastirem (Bitolja), a tym samym mogli użyć swoich sił zbrojnych na terenach, które od długiego czasu stanowiły obiekt ich zainteresowania. Jednym z takich obszarów były, dające dostęp do Adriatyku, tereny północnej Albanii, których plany opanowania opracowano w Belgradzie już pod koniec XIX w. Jednak dopiero w toku I wojny bałkańskiej nadarzyła się okazja do ich realizacji. Wykorzystując fakt, że od połowy listopada 1912 r. armia nie prowadziła poważniejszych operacji wojennych, naczelne dowództwo serbskie skierowało znaczne siły na teren Albanii. W dniu 21 listopada zajęły one Prizren, następnie Tiranę, a 29 listopada dotarły do portu Dracz, dając Serbom upragniony dostęp do morza. Tymczasem, jak już wspomniano, tereny Albanii były obszarem szczególnego zainteresowania dwóch rywalizujących o wpływy w zachodniej części Półwyspu Bałkańskiego państw - Austro-Węgier i Włoch. Stąd też akcja serbska spowodowała natychmiastową reakcję tych mocarstw ${ }^{28}$, a kwestią albańską - jako priorytetową mocarstwa zajęły się już w trakcie pierwszych posiedzeń konferencji ambasadorów w grudniu 1912 r. Kwestia ta nie była jednak łatwa do rozstrzygnięcia. W toku dyskusji nad granicami Albanii, starły się bowiem trzy koncepcje. Pierwszą reprezentowali sami Albańczycy, którzy postulowali objęcie granicami ich państwa wszystkich czterech uznawanych za albańskie wilajetów, na terenie których władze tureckie ogłosiły

zane pod nadzór rosyjski; Международнье отношения, , t. 21, cz. 1, nr 115, 204. Także pozostałe mocarstwa przeciwne były zbytniemu zbliżeniu się Bułgarów do cieśnin czarnomorskich i starały się przeforsować wyznaczenie tymczasowej strefy buforowej, której granica od strony bułgarskiej przebiegać miała wzdłuż linii: ujście Maricy - Adrianopol (obejmując miasto) - wybrzeże Morza Czarnego; zob. ibidem, nr 118; Der diplomatische Schriftwechsel Iswolskis 1911-1914, hrsg. F. Stieve, t. 2, Berlin 1926 , nr 544. Swój negatywny stosunek mocarstwa wyrażały także w odniesieniu do włączenia w granice Grecji Janiny, a zwłaszcza sprzeciwiały się planom opanowania Szkodry przez Czarnogórców.

27 Tekst dokumentu w: J. Rubacha, A. Malinowski, A. Giza, op. cit., t. 1, s. 109-110. Protokół nie został podpisany przez Grecję, która postanowiła kontynuować oblężenie Janiny. Jednocześnie rząd grecki zadeklarował, że jego delegacja weźmie udział w pertraktacjach pokojowych w Londynie; zob. Der diplomatische Schriftwechsel..., t. 2, nr 600, 603, 605, Международные отношения, t. 21, cz. 1, nr 411.

28 Już 30.10.1912 r. Berchtold oświadczył, że Austro-Węry nie dopuszczą do usadowienia się Serbów nad Adriatykiem i popierać będą ideę stworzenia niepodległego państwa albańskiego, a 08.11.1912 r. oficjalnie powiadomił o tym rząd serbski. Takie samo stanowisko przyjęły także Włochy oświadczając 04.11.1912 r., że: „korytarz serbski do Adriatyku nie da się pogodzić z interesami Włoch”; H. Batowski, Państwa, s. 197; na ten temat także: M. Tanty, Rosja, s. 104-106 i n. 
autonomię jeszcze w sierpniu 1912 r. Jednak żądań tych nie były w stanie przeforsować nawet niezwykle przychylnie nastawione do Albańczyków Włochy i AustroWęgry. Stąd też proponowały one, aby granica nowego państwa bałkańskiego przebiegała wzdłuż dotychczasowej granicy czarnogórsko-tureckiej, obejmując Szkodrę na północy, następnie biegnąc na południe pozostawić miała po stronie albańskiej $\mathrm{m}$. in.: Prizren, Dibrę i Ochrydę oraz objąć znaczną część Epiru z Janiną na południu. W opozycji do obu tych koncepcji stała propozycja wysunięta przez sojuszników bałkańskich i popierana przez Rosję. Przewidywała ona, że granice przyszłej Albanii przebiegać powinny od ujścia rzeki Mati, następnie na zachód od Czarnej Driny i dotrzeć do Morza Adriatyckiego w okolicach zatoki Vlorës ${ }^{29}$. Upór reprezentujących poszczególne koncepcje stron wielokrotnie powodował impas w rozmowach i omal nie doprowadził do wybuchu konfliktu między Austro-Węgrami a Rosją ${ }^{30}$. Ostatecznie jednak, pod koniec marca 1913, konferencja ambasadorów przyjęła projekt wysunięty przez Austro-Węgry, który tworzył państwo albańskie na obszarze 2 dawnych wilajetów tureckich - szkoderskiego i janińskiego. W cztery miesiące później mocarstwa uchwaliły statut Albanii i uznały ją za niepodległe księstwo pod protektoratem mocarstw ${ }^{31}$. Rozwiązanie to stało jednak w sprzeczności z planami Czarnogóry, która przystępując do wojny przeciw Turcji liczyła na włączenie w swe granice Szkodry oraz nadziejami Serbii na dostęp do Adriatyku. Ich protesty pozostały jednak bez echa, a na początku maja 1913 r. Włochy i Austro-Węgry zawarły porozumienie, w którym zobowiązywały się do wspólnej obrony terytorium albańskiego ${ }^{32}$. Negatywne stanowisko mocarstw Trójprzymierza zmusiło ostatecznie do ustępstw zarówno Czarnogórców, jak i Serbów, którzy wycofali swoje oddziały zarówno z północnej Albanii, jak i spod Szkodry ${ }^{33}$. Nie ulega wątpliwości, że taki stan rzeczy stanowił porażkę dyplomacji rosyjskiej, ale co istotniejsze, zacięte dyskusje, które towarzyszyły naradom w kwestii albańskiej, doprowadziły do poważnego konfliktu w łonie „koncertu europejskiego", a w kolejnych miesiącach oba bloki militarno-polityczne, zgodnie do tej pory współpracujące w zakresie szybkiego zakończenia konfliktu na Bałkanach, powróciły do zaciętej rywalizacji znanej z okresu wcześniejszego. Na taki stan rzeczy istot-

${ }^{29} \mathrm{Na}$ ten temat wiele dokumentów w Die große Politik der europäischen Kabinette, 1871-1914. Sammlung der diplomatischen Akten des Auswärtigen Amtes, hrsg. J. Lepsius, A. Mendelssohn-Bartholdy, F. Thimme, t. 34, Berlin 1922 (cyt. dalej: DGP), cz. 1

${ }^{30}$ Zob. M. Tanty, Rosja, s. 128-131.

${ }^{31}$ Zor. H. Batowski, Państwa batkańskie 1800-1923. Zarys historii dyplomatycznej i rozwoju terytorialnego, Kraków 1938, s. 198-202, E. C. Helmreich, The diplomacy of the Balkan wars, 1912-1913, Cambridge 1938, s. 296; na ten temat wiele dokumentów w: DGP, t. 34, cz. 2

${ }^{32}$ Zob. Dokumente aus russischen Geheimarchiven soweit sie bis zum 1. Juli 1918 eingegangen sind, hrsg. vom Ausvärtgen Amt, Berlin 1919, s. 38-41, na ten temat także: A. Krzyżanowski, op. cit., s. 97-115.

${ }^{33}$ Zob. Материали по истории франко-русских отномений за 1910-1914 гг. Сборник секретныч документов бывшего Императорского Российского Министерства Иностранных дел, ред. Р. Марханд, Москва 1922, s. 363. 
ny wpływ miał także postępujący rozpad bloku bałkańskiego, spowodowany sporem w kwestii podziału zdobytych na Turcji terenów w Macedonii ${ }^{34}$.

Drugi okres aktywnej działalności politycznej mocarstw na Bałkanach w okresie wojen bałkańskich, również nie przyniósł im spektakularnych sukcesów. Przedsięwzięte kroki na rzecz ograniczenia zasięgu działań wojennych, w związku z szybkimi postępami armii sprzymierzonych, nie dały spodziewanych rezultatów, a zorganizowana akcja morska w Konstantynopolu okazała się niepotrzebna. Sukcesy w tym czasie świecić mogły jedynie mocarstwa centralne, którym udało się zablokować starania wspieranej przez Rosję Serbii o dostęp do Morza Adriatyckiego, ale w kontekście znacznej przewagi wpływów włoskich w Albanii sukcesy te uznać należy za bardzo ograniczone.

Trzeci okres aktywnej działalności wielkich mocarstw na Bałkanach zawrzeć można pomiędzy końcem maja a wrześniem 1913 r. Aktywność ta koncentrowała się przede wszystkim na próbach ratowania sojuszu bałkańskiego lub próbach jego rozbicia i pozyskania któregoś z jego członków do współpracy. Szczególną aktywność na tym polu wykazywały Rosja i Austro-Węgry, a dla obu rywalizujących stron rolę szczególną odgrywała Bułgaria, zdecydowanie najsilniejsze państwo na Półwyspie Bałkańskim.

Starając się utrzymać to państwo w swojej strefie wpływów, a zarazem nie dopuścić do rozpadu bloku bałkańskiego, rosyjska dyplomacja, popierana początkowo przez partnerów z Trójporozumienia, starała się za wszelką cenę załagodzić narastający spór miedzy Sofią a Belgradem i Atenami ${ }^{35}$. Jej wysiłki okazały się jednak daremne. Brak wyraźnego poparcia przez Petersburg bułgarskich roszczeń terytorialnych w Macedonii wywołał ożywioną krytykę kręgów opozycyjnych w Bułgarii, co nie tylko dynamizowało sytuację w tym kraju, ale groziło przejęciem władzy przez czynniki antyrosyjskie. $Z$ drugiej jednak strony wyraźna niechęć rządu bułgarskiego do jakichkolwiek ustępstw na rzecz sojuszników skutecznie uniemożliwiała prowadzenie mediacji. W związku z tym Rosja ostatecznie pogodziła się rozpadem bloku bałkańskiego i zaczęła więcej uwagi poświęcać Serbii, aczkolwiek okresowo powracano w Petersburgu do idei utrzymania Bułgarii po stronie Ententy. Fakt ten postanowiły natomiast wykorzystać mocarstwa centralne. Już na początku 1913 r. dyplomacja austro-węgierska zaczęła kierować do Sofii wyraźne sygnały, że gotowa jest aktywnie wesprzeć bułgarskie roszczenia terytorialne ${ }^{36}$, ale stawiała jeden zasadniczy warunek. Bułgarzy musieli uregulować stosunki z Rumunią, która oficjalnie pozostawała w ścisłym związku z Trójprzymierzem. Tymczasem kwestia ta nie była łatwa do rozwiązania. Jeszcze przed wybuchem I wojny bałkańskiej Rumunia wyraźnie oświadczyła, że w przypadku jakichkolwiek poważniejszych zmian terytorialnych na Bałkanach zażąda rekompensaty terytorialnej za - jak to określano - zachwianie rów-

${ }^{34} \mathrm{Na}$ ten temat szerzej: J. Rubacha, op. cit., s. 266-299.

${ }^{35}$ Zob. ibidem, s. 300-301.

${ }^{36}$ Zob. DGP, t. 35, nr 13493, 13504; wiele dokumentów na ten temat w: ÖUA, t. 6; na ten temat także: М. Семов, Победителят проси мир: балканските войни 1912-13, София 1995, s. 201. 
nowagi w tym regionie. Ponieważ Rumunia nie posiadała wspólnej granicy z Turcją, swoje roszczenia skierowała do Sofii, żądając odstąpienia jej Południowej Dobrudży. Żądania te uznano w Bułgarii za nie do spełnienia, ale jednocześnie zdawano sobie sprawę z faktu, że w przypadku konfliktu z Serbią i Grecją, kraj znajdzie się w poważnym niebezpieczeństwie. Dlatego deklaracje monarchii habsburskiej, że Wiedeń chętnie podejmie się mediacji w sporze rumuńsko-bułgarskim, zostały przyjęte w Sofii z dużym zainteresowaniem. Podjęte próby osiągnięcia porozumienia, przede wszystkim na skutek stałego poszerzania zakresu roszczeń przez Rumunów, nie dały jednak żadnych rezultatów i mimo podejmowanych przez Austro-Węgry wysiłków, napiętej sytuacji nie rozwiązały bezpośrednie rozmowy toczące się od grudnia $1912 \mathrm{r}$. Tymczasem fiasko pertraktacji bułgarsko-rumuńskich wywołało duże zaniepokojenie w Europie ${ }^{37}$, ponieważ oba państwa odgrywały istotną rolę w planach obu przeciwstawnych bloków politycznych. Stąd też w działania na rzecz załagodzenia sporu włączyła się także Rosja. Warto zwrócić uwagę na fakt, że podjęte próby mediacji między stronami ${ }^{38}$, nacechowane były dużą ostrożnością tak, aby jak słusznie stwierdził H. Batowski - „utrzymać, względnie pozyskać, pierwszą i nie stracić drugiej"39. Podejmowane działania nadal nie przynosiły jednak spodziewanych rezultatów. Dlatego też ostatecznie oba mocarstwa aktywnie poparły wysuniętą $\mathrm{w}$ połowie lutego 1913 r. przez delegata Włoch markiza A. di San Giuliano ideę poddania sporu bułgarsko-rumuńskiego mediacji wszystkich mocarstw europejskich ${ }^{40} \mathrm{~W}$ trakcie specjalnie w tym celu zwołanej konferencji. Konferencja ta rozpoczęła prace 31.03.1913 r. w Petersburgu ${ }^{41}$, ale zgodnie z przewidywaniami obrady toczyły się w napiętej atmosferze i ostatecznie po ponad miesięcznych dyskusjach strony zdecydowały się je-

${ }^{37}$ Zob. DGP, t. 34, cz. 1, nr 12870, 12871.

${ }^{38}$ Ibidem, nr 12874, 12906, 12912, 12927, ÖUA, t. 5, nr 5308, 5309, 5310, 5311, 5326, 5349, 5616 i n., Der diplomatische Schriftwechsel, t. 3, nr 707.

${ }^{39}$ H. Batowski, Państwa, s. 205. Potwierdzeniem takiego stanowiska mogą być wysuwane przez Austro-Węgry koncepcje, które przewidywały nakłonienie Bułgarii do ustępstw terytorialnych na rzecz Rumunii, w zamian za poparcie jej roszczeń do Salonik lub kompensację strat na południu poprzez nabytki kosztem Serbii; zob. DGP, t. 34V, cz. 2, nr 13042, ÖUA, t. 5, nr 5585, 5586, 5895, 5618, 6023, 6025, 6034, 6076 i n. oraz zapewnienia rządu rosyjskiego, że w konflikcie bułgarsko-rumuńskim Rosja popiera stanowisko Sofii; zob. ÖUA, t. 5, nr 6026. Równocześnie jednak oba mocarstwa bardzo mocno rywalizowały między sobą. Jeszcze z początkiem 1913 r. rosyjski premier S. Sazonow w rozmowie z posłem rumuńskim w Petersburgu z naciskiem podkreślał, że Rumunia powinna ograniczyć swe żądania. Te działania Rosji wywołały natychmiastową reakcję Wiednia, gdzie oficjalnie deklarowano, że: „Rumunia nie jest sama”; Н. Станев, История на нова България 1878-1928, София 1929, s. 253, na ten temat także: M. Tanty, Rosja, s. 167-170 i n., E. C. Helmreich, op. cit., s. 374.

40 Zob. ÖUA, t. 5, nr 5799, 5832.

${ }^{41}$ Zob. ibidem, nr 6396, А. Кузманова, Румынските териториальни претенции за Южна Добруджа и Букуресзткият договор; w: Букуресзткият договор и сыдбата на Южна Добруджа, ред. А. Кузманова, Добрич 1994, s. 15; na temat przebiegu konferencji zob.: P. Kiszkilowa, op. cit., s. 10, Е. Стателова, Р. Попов, В. Танкова, История на българската дипломаџия 1879-1913, София 1994, s. 466 , wiele dokumentów na ten temat także w ÖUA, t. 6 . 
dynie na podpisanie protokołu końcowego ${ }^{42}$, którego klauzule nie satysfakcjonowały żadnej ze stron.

Tymczasem rosnące napięcie w łonie sojuszu bałkańskiego doprowadziło 30.06.1913 r. do wybuchu II wojny bałkańskiej ${ }^{43}$, do której po stronie przeciwników, a zarazem niedawnych koalicjantów Bułgarii przyłączyły się także Rumunia i Turcja. W trakcie krótkich, trwającej zaledwie miesiąc, zmagań wielkie mocarstwa nie podejmowały szerzej zakrojonych działań. Nie oznaczało to jednak zupełnego porzucenia planów pozyskania Bułgarii. Do realizacji tych planów zarówno Austro-Węgry, jak i Rosja powróciły w momencie zakończenia działań wojennych i rozpoczęcia negocjacji pokojowych w Bukareszcie na początku sierpnia $1913 \mathrm{r}$. Warto podkreślić, że jakkolwiek plany obu tych mocarstw były przeciwstawne, używały one tej samej retoryki, starając się przekonać delegację bułgarską, że postanowienia traktatu pokojowego zostaną poddane weryfikacji w trakcie konferencji wielkich mocarstw, a w jej trakcie Sofia liczyć może na szeroką pomoc dyplomatyczną. Jakkolwiek deklaracje nigdy nie zostały spełnione ${ }^{44}$, zmiana rządu w Bułgarii i przejęcie władzy przez kręgi opowiadające się za zacieśnieniem współpracy z mocarstwami zachodnimi zbliżyła ten kraj do mocarstw centralnych.

Podsumowując trzeci okres działań dyplomatycznych mocarstw na Bałkanach stwierdzić należy, że w jego trakcie doszło do ostatecznego wykrystalizowania się ścisłych więzów łączących członków poszczególnych bloków polityczno-militarnych, co w kontekście stałego wzrostu napięcia między nimi dynamizowało sytuację i groziło wybuchem konfliktu. Do jego rozpoczęcia doszło bardzo szybko, bo zaledwie rok po zakończeniu wojen bałkańskich. W tym okresie ograniczone sukcesy odniosły po raz kolejny mocarstwa centralne, którym udało im się wykorzystać rozpad sojuszu bałkańskiego, pozyskać Bułgarię i ograniczyć wpływy rosyjskie w tym kraju. Warto jednak zaznaczyć, że znaczne osłabienie zarówno Turcji, która mimo zawirowań politycznych pozostała w strefie wpływów niemieckich, jaki i Bułgarii, wycieńczonej zmaganiami w toku wojen bałkańskich, znacząco obniżało wartość tych krajów, jako partnerów politycznych, ekonomicznych i militarnych, co w pełni ujawniło się w pierwszej fazie I wojny światowej.

42 Tekst dokumentu w: J. Rubacha, A. Malinowski, A. Giza, op. cit., t. 1, s. 118-119.

${ }^{43} \mathrm{Na}$ ten temat szerzej: J. Rubacha, op. cit., s. 306-324.

44 Szczególny wpływ na taki stan rzeczy miały: obojętny stosunek Niemiec oraz obojętna postawa Francji i Wielkiej Brytanii, które udaremniły próby zwołania konferencji mocarstw; zob. C. Радев, Конференията в Букурешт и Букурештият мир от 1913 г. Мемоари, София 1992, s. 70-75, Т. v. Sosnosky, op. cit., s. 370-371. 


\title{
THE GREAT EUROPEAN POWERS AND BALKAN WARS 1912-1913
}

\begin{abstract}
Summary
Balkan Wars 1912-1913 were a milestone event in the history of the Balkans. They ending, started in 1878, process of expulsion of Turkey from its European possessions, and creating the possibility of realizing popular in this part of Europe slogan "The Balkans for the Balkan nations". It should be noted that taking on the Balkan Peninsula events were with attention watched by the european great powers, because this part of Europe they are treated as a region of special economic and politic-military interest.

This situation was dictated primarily by dynamic industrialization of Europe, which already in the middle of the nineteenth century led to the exacerbation of the struggle for access to the raw materials and especially to sales markets. In the context of the Balkans the essential importance had the rivalry between Austria-Hungary, which was seeking a safe and comfortable way to the port of Thessaloniki, and Russia, which was striving to change the status of Bosporus and the Dardanelles, for ensure grain exports through the Black Sea and the Mediterranean Sea. It must be remembered that the Balkans and Turkey played an equally important role in the economic plans of other powers - Great Britain, France, and from the late nineteenth century also Italy and Germany.

An equally important role played by political and military considerations. The entry of great powers in the so-called imperial era greatly influenced the intensification of the competition for the "undisputed leader" in Europe and the range of spheres of influence, and the crystallization of the opposing militarypolitical blocks in the Europe, pay attention of politicians to those European countries, which was created the possibility of blocking the enemy actions and obtain tactical advantage. For obvious reasons, the Balkans have played in this rivalry special role.

Although the imposition of all these factors complicated the situation on the Balkan Peninsula, the persistent tension between the great powers created Balkan states and nations the feasibility of their policy plans. Thus, in the era of the Balkan wars, they did not intend to follow the guidelines of European diplomacy, and taken by the great powers the efforts to save peace and acquisition of potential allies did not lead to the expected success, which clearly confirmed the events of WWI.
\end{abstract}

